\title{
THE IMPACT OF STRATEGIC OPERATIONS MANAGEMENT DECISIONS ON SHOPPERS' WELLBEING
}

\author{
Ahmet Demir \\ Business Management Department, Faculty of Administrative Sciences and Economics, \\ Ishik University, Sulaimani, 46001, Kurdistan Region of Iraq \\ Email: ahmet.demir@ishik.edu.iq
}

Published online: 27 June 2019

To cite this article: Demir, A. (2019). The impact of strategic operations management decisions on shoppers' wellbeing. Asian Academy of Management Journal, 24(1), 25-57. https://doi.org/10.21315/aamj2019.24.1.2

To link to this article: https://doi.org/10.21315/aamj2019.24.1.2

\begin{abstract}
Various studies have looked at the operations management field in shopping malls, but the impact of strategic decision areas on shoppers' wellbeing in malls has not been explored. This study elaborates the importance of structural and infrastructural decision areas for shoppers' wellbeing in malls. Since operations management is one of three vital departments (along with marketing and finance) of most organisations, it is important to examine how decisions in operations management of shopping malls impact shoppers' wellbeing. This paper examines the structural and infrastructural decision-areas made by shopping mall operations managers in the Kurdistan Region of Iraq to see how they impact shoppers' wellbeing. A survey questionnaire was administered to 575 shopping mall customers. IBM SPSS 23 was used to conduct exploratory factor analysis and hierarchical regression analysis. Additionally, an IBM AMOS 23 was used to conduct structural equation modelling. The results indicate that both the structural and infrastructural decision areas of operations management are significantly important in determining shoppers' wellbeing. The variance of shoppers' wellbeing in each strategic decision area is further explained. The findings of this study consist of implications for researchers and especially for practitioners. The study constructs a framework for future studies about how the operations strategic decision areas impact shopper wellbeing in malls. Furthermore, practitioners can use the findings of this study when they perform their strategic planning. Finally, those developments would influence consumers' wellbeing during their visits to shopping malls.
\end{abstract}

Keywords: operations strategy, structural decisions, infrastructural decisions, shopping malls, shoppers' wellbeing

(C) Asian Academy of Management and Penerbit Universiti Sains Malaysia, 2019. This work is licensed under the terms of the Creative Commons Attribution (CC BY) (http://creativecommons. org/licenses/by/4.0/). 


\section{INTRODUCTION}

Since the early 1970s, corporate strategy in manufacturing has been an important subject (Hayes \& Wheelwright, 1984; Kim \& Lee, 1993; Skinner, 1969; Swamidas $\&$ Newell, 1987). Researchers in this field suggest that operations management is a source of sustainable competitive advantage and must be integrated into the strategic processes of an organisation. However, operational strategic decisions, which are mainly service and product design, quality management, capacity design, location, layout design, human resources and job design, supply-chain management, inventory management, scheduling, and maintenance (Heizer \& Render, 2011), are required for all managers in their capacity to perform their planning, organising, staffing, leading, and controlling during the managerial process. Hayes and Wheelwright (1984) have suggested that the strategic decision-making of operations management should be separated into structural and infrastructural decision areas. They indicate that those decision areas affect a firm's capacity to meet organisational goals (Smith \& Reece, 1999).

Structural decisions are referred to as the allocation of physical and tangible resources that are meant to offer optimal convenience in service delivery (Fan, French, Duray, \& Stading, 2017) or manufacturing. This type of decision relies on the managers' resource planning capacity, an ability that may help the managers to conform to the demands of various operational activities (Roth \& van Dierdonck, 1995). Generally, these activities involve long-term facility and service choices (Li, Benton, \& Leong, 2002). However, various researchers have selected different structural tools, such as plant and equipment (Skinner, 1969), capacity and facilities (Hayes \& Wheelwright, 1984; Kim \& Arnold, 1996), and location (Buffa, 1984; Krajewski \& Ritzman, 2000). These suggested differences show that there is no specific consensus on structural decisions among researchers.

The other decision area is the infrastructure. Infrastructural decisions are mostly intangible tools such as quality (Hayes \& Wheelwright, 1984; Kim \& Arnold, 1996), organisation (Diaz-Garrido, Martin-Pena, \& Garcia-Muina, 2007), and human resources management (Fine \& Hax, 1985). However, infrastructural elements do not necessarily require as large an investment as do structural elements (Diaz-Garrido et al., 2007). Moreover, despite less interest in infrastructural decisions (Narasimhan, Swink, \& Kim, 2005; Swink, Narasimhan, \& Kim, 2005), it is believed that this factor carries high importance in the service sector.

Although there are similarities in determining structural and infrastructural decisions in the operations management field, researchers have preferred to compare different dimensions. This fact shows that despite structural and infrastructural 
decisions being significantly important in every industry, they show similarities and differences from one sector to another.

Many researchers have studied structural and infrastructural decisions in the manufacturing (Diaz-Garrido et al., 2007; Narasimhan et al., 2005; Swink et al., 2005) and service sectors (Espino-Rodríguez \& Gil-Padilla, 2015; Jones \& Lockwook, 1998). However, only a limited number of researchers have studied structural and infrastructural decisions in shopping malls. For this reason, the current research is focused on shopping malls. It is suggested that service and product design, quality management, capacity design, location, layout design, and finally, human resources and job design must be applied to shopping malls with the utmost caution. Additionally, Noble (1995) has suggested that operations capabilities and operational decision areas must be set in a path-dependent way in order to be reciprocally reinforced. This information shows us that decisions in operations management reinforce one another. In this study, we have considered structural decisions to be location, layout, design, and capacity, while infrastructural decisions are seen as quality and human resources.

Shopping malls have brought tremendous changes and advantages to the lives of many in societies (Chotipanich \& Issarasak, 2017) throughout the world since the second half of the 20th century. These malls have become popular locations for customers as a place to shop, entertain, socialise, relax, and interact (Feinberg \& Meoli, 1991; Osman, Johns, \& Lugosi, 2014). Such places have become an entity for most modern societies as people shop and socialise at the same time, simultaneously creating recreational activities for themselves (Graham, 1988). How these shopping malls are managed and how they operate is an important issue in making shoppers and other customers feel more relaxed during their visits, as it can lead to future visits.

Various dimensions of the shopping mall have been studied (Keng, Huang, Zheng, \& Hsu, 2007; Lehew, Burgess, \& Wesley, 2002). These studies have focused on shopping malls and social diversities (Michon \& Chebat, 2004), social and psychological aspects of shopping (Alary Gauvreau, Kairy, Mazer, Guindon, \& Le Dorze, 2018; Bloch, Ridgway, \& Dawson, 1994; Rosenbaum, Otalora, \& Ramírez, 2016; Roy, 1994), age effects and shopping (Anselmsson, 2006), gender effects and shopping (Chebat, Gélinas-Chebat, \& Therrien, 2005; Hu \& Jasper, 2004; Raajpoot, Sharma, \& Chebat, 2007), excitement and shopping (Kesari \& Atulkar, 2016; Kim \& Jin, 2001; Tsai, 2010; Wakefield \& Baker, 1998), designs of shopping malls (Chebat \& Morrin, 2007; Dogu \& Erkip, 2000; Hami, Moula, \& Maulan, 2018; Shang et al., 2016; Turley \& Chebat, 2002), facility management (Chotipanich \& Issarasak, 2017), and other matters. Although these studies give 
important information on mall shoppers and customers, no study has attempted to look at the operational strategic decision areas as aspects that may impact mall shoppers' wellbeing.

Shopping malls have strongly emerged onto the scene in the Kurdistan Region of Iraq, particularly after the end of the United Nations Embargo in 2003 (Demir, Özmen, \& Rashid, 2014). Among these are some of the largest shopping malls, such as the Majidi Mall and the Family Mall, which were opened in Erbil and Sulaimani, respectively, after 2010. Observations show that there has been an increasing number of customers patronising and selecting these malls for their retail shopping due to the designs of the malls.

This study investigates the impact of structural and infrastructural decisions on the shoppers' wellbeing in malls. To do this, the study aims to examine various shopping malls that are located in the Kurdistan Region of Iraq. Seven shopping malls have been chosen for the study because they have been visited by thousands of customers and they are the most popular shopping malls in the region. For this purpose, the study focuses initially on the elaboration of operational strategic decisions, and second, on their impact on mall shoppers' wellbeing.

In the literature review section, the study explains how operational strategic decisions are divided into sections and how they have been studied in various research. Second, it explains what wellbeing is, and according to the previous studies, what are some determinants of it. In the methodology section, the main purpose of the study, data collection, and analysis methods have been briefly explained. Further, the study model has been graphed in that section. In the findings part, the outcomes of the study and analysis results of the collected data have been set forth. In the discussion, the similarities and differences of various studies compared to this study are explained. Finally, focus points, main outcomes, limitations, and suggestions for further studies have been proposed.

The outcome derived from this study has shown the impact of shopping malls' operational strategic decisions on shoppers' wellbeing. Based on the outcome, it is believed that this area of investigation, the operations management field, remains an underestimated factor in determining shoppers' wellbeing in the Kurdistan Region of Iraq. Since this element can be used to explain approximately $46 \%$ of the reasons why shoppers project quality perceptions onto those shopping malls, they need to be taken into consideration in future studies. 


\section{CONCEPTUAL MODEL AND HYPOTHESIS}

Based on Skinner's pioneer work (1969), Voss (1995) has identified three theoretical frameworks for the operations strategy. The first of these paradigms is operations in order to compete and considers manufacturing as a mere competitive element. The second framework is based on internal and external operational consistency, and the final framework is based on the positive influence of best operational practices. However, there is much research on operations strategy (Hayes \& Wheelwright, 1984; Buffa, 1984), and those studies suggest that operations decisions impact a firm's global strategy. Additionally, there is no specific consensus among scholars about the establishment of decision areas in operations management strategies.

Some authors (e.g., Hayes \& Wheelwright, 1984) have directly identified operations strategic decisions within the strategies of an organisation. Thus, organisations are positioned conveniently in case they determine competitive priorities and can support those priorities with the requisite operational strategic decisions. Moreover, most of the authors have gathered those decisions under two main domains: structural decisions and infrastructural decisions. Additionally, Noble (1995) has suggested that operations capabilities and operational decision areas must be set in a path-dependent way in order to be reciprocally reinforced. This information shows us that decisions in operations management reinforce one another.

Thus, in this study, we have elaborated the strategic operational decision areas in shopping malls. In this section, we also investigate the theoretical background of the study.

\section{Operations Management in Service Sector}

Service production is increasing rapidly all over the world. For this reason, operations management studies are significantly predisposed to the service production field (Halkjær \& Lueg, 2017; Harvey, 1990; Hyer, Wemmerlöv, \& Morris Jr., 2009; Messner, 2016; Patel, Guedes, \& Pearce, 2017; Ren \& Huang, 2017; Subramanian \& Ramanathan, 2012). Operations management departments play an important role in the service sector. Although service operations management is similar to manufacturing operations, to some extent, there is one critical difference. This involves the role of the customers, who can either increase or decrease their visits to the mall. Thus, the strategic source of variation in the service delivery process of shopping malls needs to be given some attention (Mohar, Abdullah, \& Hoo, 2016). 


\section{Ahmet Demir}

There are three vital departments in each organisation that manages shopping malls, and they include operations management, marketing department, and finance department (Collier \& Evans, 2014). As one of the vital departments, operations management is responsible for processing every step of the operations that converts the input of goods into a service output.

The operations management department needs to deal with 10 strategic-decision fields that account for the planning, programming, and controlling of those processes. These decision fields include product and service designs, location, layout, quality management, capacity design, human resources and job design, supply-chain management, inventory management, scheduling, and maintenance. These decision fields or areas can be evaluated within two phases: structural decisions and infrastructural operation decisions (Diaz-Garrido et al., 2007; Fan et al., 2017; Hayes \& Wheelright, 1984; Heineke, 1995; Hill, 1993).

\section{Structural Decision Areas}

\section{Location}

In some service industries, survival may significantly depend on the location strategy alone (Henry, 1994; Hudson, 1995). In this study, the location strategy is evaluated by focusing on the shopping malls operations' decisions on how they locate their facilities. The location decision may show a change from one business sector to another. For instance, considering industrial location strategies, minimising costs are usually the main goal, while for service organisations, it focuses on maximising revenue (Heizer, Render, Munson, \& Sachan, 2017).

Location strategy means selection of the best place for visitors so that they may easily reach the shopping mall with less traffic and time consumption. This strategy is one of the important aspects of increasing the number of visitors to a shopping mall. As it is the shopping mall operators' responsibility to select the most critical and convenient place in the market to provide service to their customers, the location of the specific sections of the mall hold important roles in offering their services (Ketokivi, Turkulainen, Seppälä, Rouvinen, \& Ali-Yrkkö, 2017). These services are comparatively outstanding, such that they are unavailable online or they are so people-oriented that similar services would encourage shoppers to return to the same mall repeatedly.

The importance of location comes from the requirement for businesses to be close to market demand (Goldstein, Ward, Leong, \& Butler, 2002). Four main methods are used in solving location problems: the factor-rating method, locational cost- 
volume analysis, the centre-of-gravity method, and the transportation model (Heizer et al., 2017). For shopping malls, locations must be where customers can easily gain access. In the Kurdistan Region of Iraq, shopping malls are locations that people visit to purchase clothes and groceries, enjoy entertainment such as the cinema and fast-food restaurants, etc. It can be said that people mostly visit malls for socialising. Selection of the best locations plays an important role.

It is important for operations managers to ensure customers can easily reach the location, that there are various ways to reach it, and there are no traffic jams while driving to it. If so, the location of the mall has been selected well from the customers' perspective. Thus, the hypothesis formulated for this area is as follows:

H1: Strategic location decisions impact the quality perceptions of shopping mall customers.

\section{Layout}

A good layout is defined as a workplace that is conveniently designed for an appropriate service provision. This strategy may be used in warehouses or in the manufacturing and service fields (Ivanov, Tsipoulanidis, \& Schönberger, 2017). The layout of an organisation is a highly important and strategic decision area because it impacts the efficiency of the operational activities in the long run. This has been endorsed by Heizer and Render (2011) who stated that, "an effective layout can help an organization to achieve a strategy that supports differentiation, low cost, or response". The current global environment has dramatically decreased the life cycle of products and increased mass customisation demand such that layout strategies also must be dynamic. Furthermore, according to Heizer et al. (2017):

To make quick and easy changes in product models and in production rates, operations managers must design flexibility into layouts. To obtain flexibility in layout, managers must cross-train their workers, maintain equipment, keep investments low, place workstations close together, and use small, movable equipment.

As location strategy is about where an organisation operates, layout strategy is about where to locate equipment, tools, and departments for a convenient production run in a manufacturing or service industry. Operations managers must discuss how to achieve the following (Heizer et al., 2017):

- Higher utilisation of space, equipment, and people

- Improved flow of information, materials, and people 
- Improved employee morale and safer working conditions

- Improved customer/client interaction

- Flexibility (whatever the layout is now, it will need to change)

Therefore, the layout strategies of the shopping malls being examined are evaluated for their ease in enabling customers to find the relevant stores, restaurants, restrooms, and all other facilities, at their convenience and in accordance with layout decisions. Based on this, the hypothesis formulated for this decision area is as follows:

H2: Strategic layout decisions impact the quality perceptions of shopping mall customers.

\section{Service and product design}

Service and product designs are undisputedly key success factors (Damali, Miller, Fredendall, Moore, \& Dye, 2016; Hermann, Huber, \& Braunstein, 2000) in any organisation. Designing a service is generally a difficult issue because it needs to include unique characteristics in every sector and business. The right dose of service should be able to generate more customer interactions in the shopping mall business compared to the manufacturing sector (Heizer \& Render, 2011). As successful layout design is focused on the ease of finding the desired facility, design strategy evaluates how beautifully and conveniently those facilities have been arranged from the colour, shape, and architectural points-of-view.

In this study, the structural decision area is evaluated based on the design or architecture of the shopping malls. This is because the design is the key driver of the performance of the malls. Shopping mall designers also have substantial latitude in choosing product architecture, which is an important managerial decision (Ulrich, 1995). Thus, the designing strategy is evaluated based on how the mall looks architecturally, how suitably it is decorated, and whether or not the design is attractive to customers. Based on this, the hypothesis formulated is as follows:

H3: Strategic product design decisions impact the quality perceptions of shopping mall customers. 


\section{Capacity}

Capacity is another structural decision area. It refers to the number of units that can hold, receive, or serve customers. Capacity requirements are generally related to large capital investments as fixed costs (Heizer et al., 2017). If the capacity of a facility is smaller than actual demand, a firm may lose customers. On the other hand, if the facility is larger than the demand, it is a waste of financial resources and a redundant investment. Operations managers must make good estimates of capacity-demand in the short, medium, and long run. To do this, demand forecasting plays an important role.

Studies show that the actual capacity is usually lower than the planned capacity (Ivanov et al., 2017). The designed capacity of the mall serves as the peak for demand and where a system can provide a particular service. In the current study, capacity is evaluated as the spaces of shops, such as the dining and entertainment areas, or the parking capacity of the respective malls. Based on this, the hypothesis formulated is as follows:

H4: Strategic capacity planning decisions impact the quality perceptions of shopping mall customers.

\section{Infrastructural Decision Areas}

\section{Quality management}

Quality management is another aspect of shopping mall strategic decision-making. This aspect includes policies, processes, procedures, and other related instructions of a system. Quality management is measured by gathering and analysing data and then using the outcome derived from the data to plan for further development (Crosby \& Free, 1979; Deming \& Edwards, 1982; Juran, 1988).

Quality can be defined as "the totality of features and characteristics of a product or service that bears on its ability to satisfy stated or implied needs" (Prince, 1994). Quality has three aspects: user based, manufacturing based, and product based (Garvin \& Quality, 1984). User-based quality requires better performance, a variety of features, and sometimes even costly improvements. Manufacturingbased quality requires the maintenance of standards determined by the operations managers. It can also be defined as "doing it right the first time and every time". Finally, product-based quality requires measurable and precise variables (Heizer et al., 2017). 


\section{Ahmet Demir}

In the service sector, customers have some expectations in mind. They usually compare the actual service provisions of one company to that of an alternative firm. In this study, quality management is evaluated through continued improvement of customer service in the shopping malls. Based on this, the formulated hypothesis is as follows:

H5: Strategic quality management decisions impact shopping wellbeing in shopping malls.

\section{Human resources}

Human resource is a strategic field in management. It refers to utilising human resources capably. The objective of a human resources management strategy is to manage the workforce and design work so that employees are utilised effectively and efficiently (Heizer et al., 2017). It is an important department of any organisation. An effective human resources department can help an organisation manage its human resources capital more effectively (Youndt, Snell, Dean, \& Lepak, 1996). Human resource management includes the planning of work schedules for employees (Heizer \& Render, 2011). Such planning can ensure that there will be a sufficient number of workers at the service location at any one time to serve customers.

Wright and McMahan (1992) have defined strategic human resource management as "the pattern of planned human resource deployments and activities intended to enable an organization to achieve organizational goals". Out of this definition, we can move in two directions:

1. Linking human resource management with the strategic management process of the organisation.

2. Managing the human resources of each department in coordination with other departments.

In the current study, human resource management refers to a number of elements including the existence of a sufficient number of employees each time they are needed, the professionalism of the employees, their level of friendliness to the customers, their level of helpfulness, and how professionally attired they are in the shopping malls. The formulated hypotheses of this area are as follows:

H6: Strategic human resource management decisions impact shoppers' wellbeing in shopping malls. 
H7: Strategic human resource management decisions impact the quality perceptions of customers in shopping malls.

\section{Shoppers' wellbeing}

Shoppers' wellbeing can be defined as customer satisfaction within different customer life subdomains (Day, 1987). Some commercial locations such as shopping malls might promote that wellbeing (Anderson et al., 2013). Rook (2015) supports that idea by stating "social psychological literature provides compelling evidence that social network involvement is positively linked to health and wellbeing across an individual's life span". Due to shopping malls being kinds of socialising locations, it can be understood that these locations increase the wellbeing of visitors. Additionally, Rosenbaum et al. (2016) state that, "shopping malls may enhance customers' wellbeing by incorporating natural green spaces and places for social interactions and relaxation". This statement further implies that there must be specific features of shopping malls that impact customers' wellbeing.

Shoppers' wellbeing might eliminate the negative effects of social exclusion (Dennis, Alamanos, Papagiannidis, \& Bourlakis, 2015). Furthermore, it can be said that the higher hedonic values customers have in an atmosphere, the higher wellbeing they may perceive (Papagiannidis, Bourlakis, Alamanos, \& Dennis, 2017). On the other hand, Taylor, Bates, and Webster (2011) stated that, "the lack of financial resources can restrict access to goods, services and participation, which can have a negative effect on happiness and wellbeing".

From this point of view, it can be said that shoppers' wellbeing contributes to their various kinds of satisfaction in life. Lee, Sirgy, Larsen, and Wright (2002) stated that, "to measure consumer wellbeing, one needs to specify the subdomains of consumer life". This is endorsed by Sirgy, Meadow, and Samli (1995) who noted that there is no specific consensus that has emerged in this field. El Hedhli, Chebat, and Sirgy (2013) and Dick and Basu (1994) have likewise found that shoppers' wellbeing contributes to their loyalty and is spread by them through positive wordof-mouth reports.

\section{METHODOLOGY}

This study investigates the impact of structural and infrastructural decision areas on shoppers' wellbeing in malls. In this context, a survey was conducted and a questionnaire that includes 6 of the 10 operational strategic decision areas was 
administered to 575 shopping mall customers. According to Israel (1992), for a population of more than 100,000 a minimum 384-person sample should be collected. With the total population of Sulaimani thought to be 1,783,270 (Ahmed, 2016), a 385-person sample would be enough for minimum sampling. For random sampling, a stratified sampling procedure has been proposed. For this purpose, in the initial stage, the questionnaire was administered to 700 participants. Approximately 100 customers were approached in each shopping mall. However, 125 of the answers were eliminated due to incompleteness in responses. Consequently, only 575 of the questionnaires were suitable for use in further analysis.

The data have been obtained by students of an operations management class. They have experience from previous projects conducted in past years. The students have been divided into sub-groups, and they collected the data from seven different shopping malls. Shopping mall customers have been selected randomly. The visitors have answered the questions asked by students one-by-one. Most of those visitors were locals. The questionnaire was conducted from afternoon until night, as these were the most crowded hours of the malls.

Survey questionnaires were designed after discussion with practitioners and researchers in this field. Moreover, as a result of these discussions, it was concluded that supply-chain management, inventory management, scheduling, and maintenance strategic decision areas might not be directly perceived by customers, so only service and product design, quality management, capacity design, location, layout design, and human resources, and job design variables have been taken into account. These six-decision areas were divided into two parts: structural decisions and infrastructural decisions. Structural decisions in this research include capacity, layout, location, and service and product design. Infrastructural decisions include quality questions and human resource matters.

Data were obtained from the survey and an analysis was conducted by using IBM SPSS 23 for exploratory factor analysis and hierarchical regression analysis and AMOS 23 software for structural equation modelling (SEM). SEM analysis was employed in order to elaborate on the impact of the path coefficients of each variable. This is followed by a hierarchical regression analysis, which is used to elaborate on the explained variance of the shopping wellbeing of customers according to each variable. Finally, the results were used to determine some strategic advice and recommendations for shopping mall business investors.

The conceptual model of this study is shown in Figure 1. The questions noted in the questionnaire were extended to two experts in the operations management field and four directors of shopping malls in the Kurdistan Region of Iraq. This was 
to ensure that the questions were relevant and appropriate. All the respondents answered all the questions in the questionnaire. The 5-point Likert scale was selected for the responses where " 1 = strongly disagree" and " 5 = strongly agree".

Since it was hypothesised that the strategic decision areas of operations management can have a significant impact on shoppers' wellbeing, the current study did not test the consequences of shoppers' wellbeing. Only the impact of the strategic operations management decisions on shoppers' wellbeing is being assessed.

Li et al. (2002) have evaluated the impact of structural decision areas on infrastructural decisions. The relevant performance of hospitals has been evaluated through intermediate operations decisions or infrastructural decision areas. In that study, infrastructural decision areas were mediators in the model. In this study, infrastructural decision areas are also mediators for the shoppers' wellbeing. The model of the study is depicted in Figure 1.

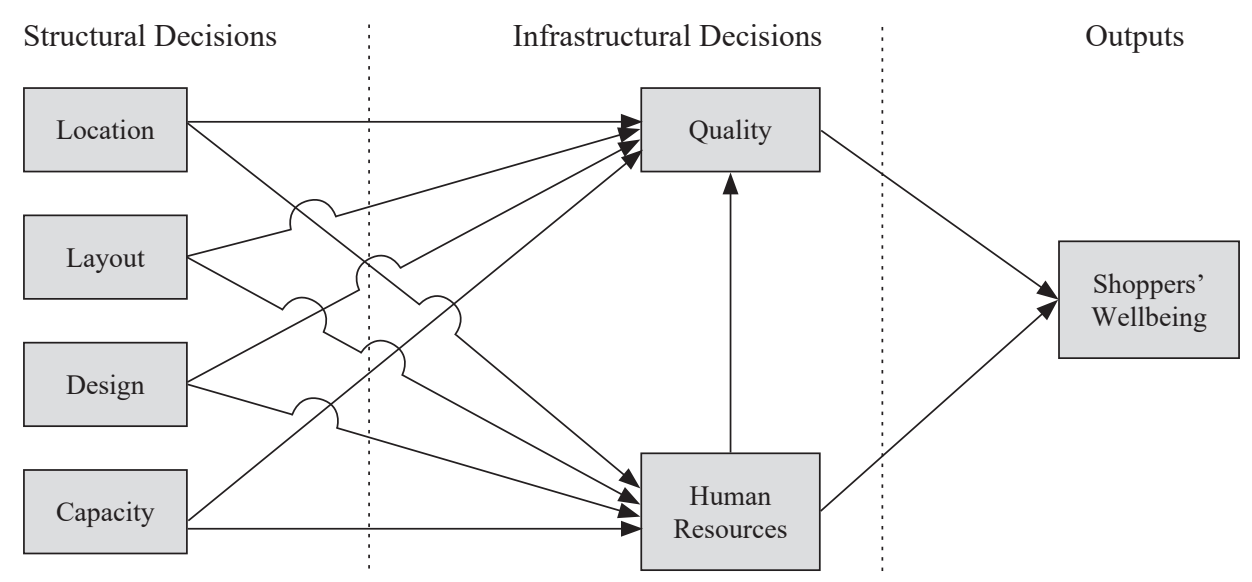

Figure 1. Model of the study

\section{Validity and Reliability}

Before the SEM was proposed, the validity and reliability of the survey questionnaire were first tested. Internal reliability was tested by Cronbach's alpha (Cronbach, 1951). The values of the dimensions were above 0.70 (Khine, 2013; Nunnally, 1978). Following the above, exploratory factor analysis was proposed to reduce dimensions that may have reflected the number of latent constructs. It was observed that the Kaiser-Meyer-Olkin's measured result was 0.941 , which is well above 0.50 , and Barlett's test of sphericity was significant at $p=<0.01$ (Field, 2000). This was then followed by another parameter of measurement, which is 
the Eigenvalue of each factor. Here, it was observed that the Eigenvalue of each factor must be equal to or above one so that the concerning cluster of questions can be considered as a factor (Field, 2000). According to the results noted in the current study, there were seven dimensions that had an Eigenvalue of above one. In addition, those factors were able to explain $69 \%$ of the variance. The remaining factor loads, Cronbach's alpha values, and dimension names of the questions are illustrated in Table 1.

\section{Confirmatory Factor Analysis (CFA)}

This study also proposed using the CFA to test whether a group of measures can adequately construct a dimension (Saunders, 2000; Straub, Boudreau, \& Gefen, 2004). To accomplish this, IBM SPSS 23 and IBM AMOS 23 software were employed. Two main types of model fit values, comparative fit and absolute fit, were also applied. The absolute fit values noted in this study were represented by chi-square $\left(\mathrm{X}^{2}\right)$, Root Mean Square Error of Approximation (RMSEA), goodness of fit index (GFI), and adjusted goodness of fit index (AGFI). In contrast, the comparative fit values (CFI) were evaluated using Trucker-Lewis' coefficient (TLI) and the incremental fit index (IFI). In this study, the $\mathrm{X}^{2} / \mathrm{DF}$ was 2.403 , which is an acceptable value since it is below 5 (Marsh \& Hocevar, 1988). The RMSEA is the discrepancy between the population covariance matrix and the covariance matrix of the hypothesised model. In the current study, the concerning value was 0.49, which show a good fit (Byrne, 2001). The GFI and the AGFI values were 0.92 and 0.90 , respectively. The results also show a good model fit (Khine, 2013).

The comparative fit indices result also showed the correctness of the hypothesised model. Here, the IFI, TLI, and CFI values were observed as $0.95,0.94$, and 0.95 , respectively. These results also showed a good fit of the model (Olobatuyi, 2006; Ong \& van Dulmen, 2007), as shown in Table 2.

The factor loads of each question under each dimension must hold a value that is equal to or above 0.5 (Hair, Black, Babin, Anderson, \& Tatham, 2006; Kim, 2014). In this study, it was observed that all the questions have been above the concerning values except for questions $8,10,11$, and 12 . Consequently, these questions were excluded from the analysis. A detailed table is attached in the Appendix. 
Operations Management in Shopping Malls

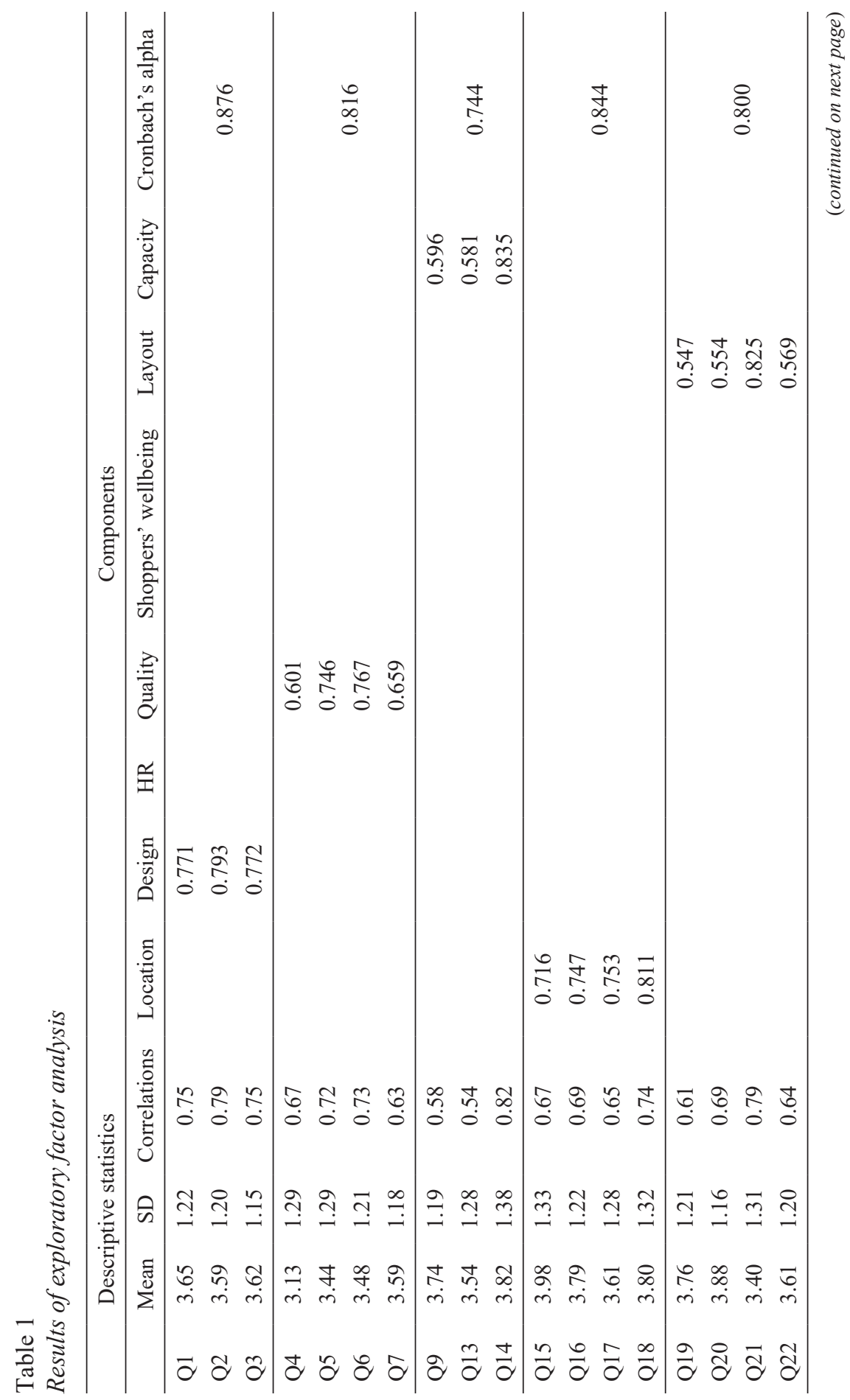




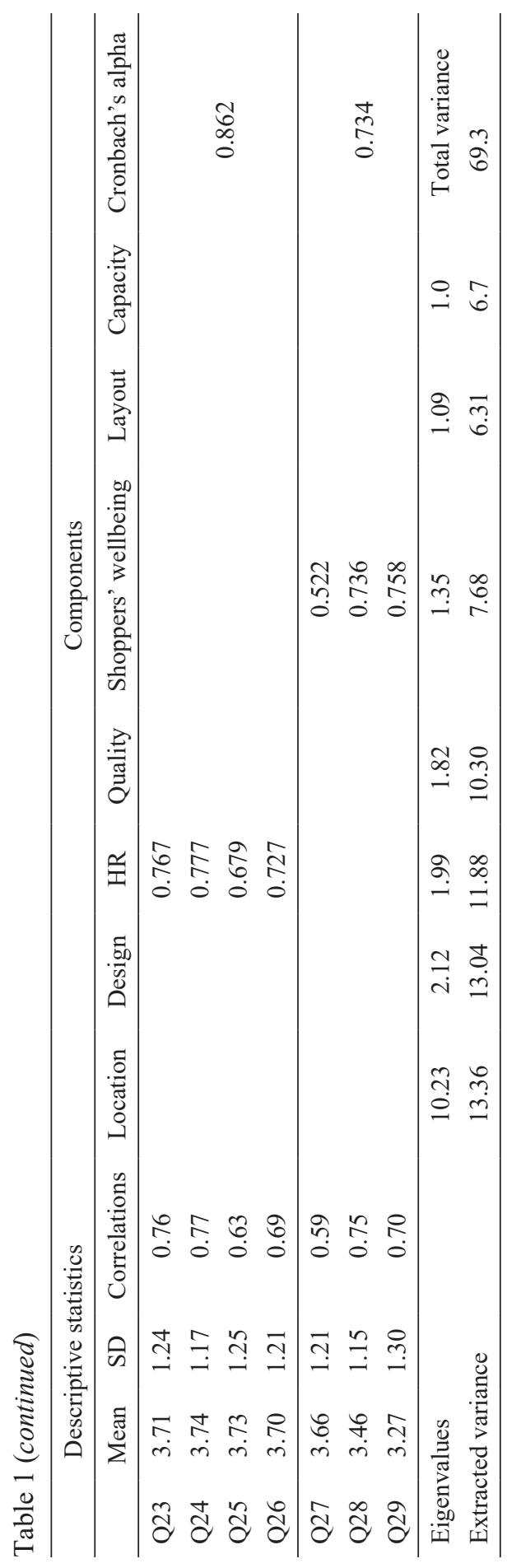


Table 2

Model fit indices of CFA

\begin{tabular}{ccccccccc}
\hline & Chi-square & Chi-square/DF & RMSEA & GFI & AGFI & IFI & TLI & CFI \\
\hline Measurements & 598.285 & 2.403 & 0.049 & 0.92 & 0.9 & 0.95 & 0.94 & 0.95 \\
\hline
\end{tabular}

In this study, all the variables survived discriminant and convergent validity. Discriminant validity tests the uniqueness of a variable by calculating the distinctness, while convergent validity tests whether the concerned underlying questions are strongly correlated with each other (Khine, 2013). Convergent validity can be assessed by the average variance extracted (AVE), which must have a value above 0.50 , and the composite reliability (CR), which must have a value above 0.70 (Fornell \& Larcker, 1981). Table 3 demonstrates the discriminant and convergent validity results.

Table 3

Convergent and discriminant validity

\begin{tabular}{lccccccccc}
\hline Variable & CR & AVE & Capacity & Quality & Location & Layout & HR & Design $\begin{array}{c}\text { Shoppers' } \\
\text { wellbeing }\end{array}$ \\
\hline Capacity & 0.83 & 0.68 & 0.89 & & & & & & \\
Quality & 0.88 & 0.64 & 0.73 & 0.80 & & & & & \\
Location & 0.89 & 0.67 & 0.74 & 0.60 & 0.82 & & & & \\
Layout & 0.84 & 0.58 & 0.87 & 0.76 & 0.80 & 0.86 & & & \\
HR & 0.92 & 0.73 & 0.75 & 0.76 & 0.68 & 0.82 & 0.86 & & \\
Design & 0.90 & 0.75 & 0.79 & 0.78 & 0.57 & 0.75 & 0.70 & 0.87 & \\
Shoppers' & 0.81 & 0.59 & 0.82 & 0.77 & 0.57 & 0.76 & 0.78 & 0.70 & 0.87 \\
wellbeing & & & & & & & & & \\
\hline
\end{tabular}

\section{Structural Equations Modelling (SEM)}

The SEM model was developed from the seven variables, where four of them were structural strategic decision areas and two of them were infrastructural strategic decision areas. The last variable was the shoppers' wellbeing, which has been considered as the outcome of other independent variables. IBM AMOS 23 software was employed for the analysis.

It is known that the SEM tests direct and indirect effects of the independent variables on the dependent variables. In this study, a maximum likelihood model of the SEM is engaged. Here, it can be said that in the operations management field, the SEM is the most used covariance structure model (Shah \& Goldstein, 2006). It allows for a widely inclusive mean that can be used to evaluate and modify the hypothesised model (Li et al., 2002). 


\section{FINDINGS}

This section presents the overall results and findings derived from the hypothesised model. Table 4 includes some participant demographic identity information. Initially, participants were mostly between $18-55$ years old. A cluster of the sample population was young, from 18 up to 35 years old, and they represented approximately $80 \%$ of the overall sample population. Evaluating the gender of the sample population, it can be seen that $38 \%$ were female, while $62 \%$ were male. Overall, $75 \%$ were of Kurdish nationality and 30\% were of Arabic nationality. Only $2 \%$ of the participants were Turkmen, and the remaining respondents were from other nationalities. Finally, evaluating the education level of the participants, it was observed that approximately $8 \%$ had less than a high school degree, $33 \%$ had high school degrees, $45 \%$ held bachelor degrees, and 14\% had more than bachelor degrees.

Table 4

Demographic distribution of the sample population

\begin{tabular}{|c|c|c|c|c|c|c|}
\hline & & & Frequency & $\%$ & Valid \% & Cumulative $\%$ \\
\hline \multirow[t]{9}{*}{ Age } & Valid & Not applicable & 5 & 0.9 & 0.9 & 0.9 \\
\hline & & Below 18 & 26 & 4.5 & 4.7 & 5.6 \\
\hline & & $18-25$ & 250 & 43.5 & 45.4 & 51.0 \\
\hline & & $26-35$ & 171 & 29.7 & 31.0 & 82.0 \\
\hline & & $36-45$ & 73 & 12.7 & 13.2 & 95.3 \\
\hline & & $46-55$ & 26 & 4.5 & 4.7 & 100.0 \\
\hline & & Total & 551 & 95.8 & 100.0 & \\
\hline & Missing & System & 24 & 4.2 & & \\
\hline & Total & & 575 & 100.0 & & \\
\hline \multirow[t]{6}{*}{ Gender } & Valid & Not applicable & 1 & 0.2 & 0.2 & 0.2 \\
\hline & & Male & 350 & 60.85 & 63.43 & 71.6 \\
\hline & & Female & 207 & 36.0 & 37.45 & 100.0 \\
\hline & & Total & 552 & 96.0 & 100.0 & \\
\hline & Missing & System & 23 & 4.0 & & \\
\hline & Total & & 575 & 100.0 & & \\
\hline
\end{tabular}

(continued on next page) 
Table 4 (continued)

\begin{tabular}{|c|c|c|c|c|c|c|}
\hline & & & Frequency & $\%$ & Valid \% & Cumulative $\%$ \\
\hline \multirow[t]{8}{*}{ Nationality } & Valid & Not applicable & 2 & 0.3 & 0.4 & 0.4 \\
\hline & & Kurdish & 412 & 71.7 & 74.8 & 75.1 \\
\hline & & Arabic & 115 & 20.0 & 20.9 & 96.0 \\
\hline & & Turkmen & 12 & 2.1 & 2.2 & 98.2 \\
\hline & & Others & 10 & 1.7 & 1.8 & 100.0 \\
\hline & & Total & 551 & 95.8 & 100.0 & \\
\hline & Missing & System & 24 & 4.2 & & \\
\hline & Total & & 575 & 100.0 & & \\
\hline \multirow[t]{8}{*}{ Education } & Valid & Not applicable & 4 & 0.7 & 0.7 & 0.7 \\
\hline & & $\begin{array}{l}\text { Primary/ } \\
\text { secondary school }\end{array}$ & 43 & 7.5 & 7.9 & 8.6 \\
\hline & & High school & 177 & 30.8 & 32.5 & 41.1 \\
\hline & & Bachelor & 245 & 42.6 & 45.0 & 86.1 \\
\hline & & $\begin{array}{l}\text { Master/ } \\
\text { PhD degree }\end{array}$ & 76 & 13.2 & 13.9 & 100.0 \\
\hline & & Total & 545 & 94.8 & 100.0 & \\
\hline & Missing & System & 30 & 5.2 & & \\
\hline & Total & & 575 & 100.0 & & \\
\hline
\end{tabular}

\section{Results Derived from SEM}

This study employed several indices to evaluate the results of the overall model. These indices include the $\mathrm{X}^{2} / \mathrm{DF}$, RMSEA, GFI, AGFI, CFI, TLI, and IFI. When the results of these values were considered, it was observed that the values were $2.553,0.51,0.915,0.895,0.93,0.925$, and 0.920 , respectively. These results reflect an adequate value of the hypothesised model, as shown in Table 5.

Table 5

Model fit indices

\begin{tabular}{ll}
\hline Model goodness of fit statistics & Value \\
\hline Chi-square/DF & 2.553 \\
RMSEA & 0.051 \\
GFI & 0.915 \\
AGFI & 0.895 \\
CFI & 0.931 \\
IFI & 0.921 \\
TLI & 0.925 \\
\hline
\end{tabular}




\section{Ahmet Demir}

Table 5 (continued)

\begin{tabular}{|c|c|c|c|c|c|c|c|c|}
\hline & \multicolumn{2}{|l|}{ Variable } & \multicolumn{3}{|c|}{ Standardised loading } & \multicolumn{2}{|c|}{$t$-value } & $p$-value \\
\hline Q7 & \multicolumn{2}{|l|}{ Quality } & \multicolumn{3}{|c|}{0.731} & \multicolumn{2}{|c|}{14.545} & $<0.01$ \\
\hline Q6 & \multicolumn{2}{|l|}{ Quality } & \multicolumn{3}{|c|}{0.723} & \multicolumn{2}{|c|}{15.233} & $<0.01$ \\
\hline Q5 & \multicolumn{2}{|l|}{ Quality } & \multicolumn{3}{|c|}{0.733} & \multicolumn{2}{|c|}{15.373} & $<0.01$ \\
\hline Q4 & \multicolumn{2}{|l|}{ Quality } & \multicolumn{3}{|c|}{0.756} & \multicolumn{2}{|c|}{ Scaling } & $<0.01$ \\
\hline Q18 & \multicolumn{2}{|l|}{ Location } & \multicolumn{3}{|c|}{0.800} & \multicolumn{2}{|c|}{ Scaling } & $<0.01$ \\
\hline Q17 & \multicolumn{2}{|l|}{ Location } & \multicolumn{3}{|c|}{0.724} & \multicolumn{2}{|c|}{17.013} & $<0.01$ \\
\hline Q16 & \multicolumn{2}{|l|}{ Location } & \multicolumn{3}{|c|}{0.761} & \multicolumn{2}{|c|}{18.912} & $<0.01$ \\
\hline Q15 & \multicolumn{2}{|l|}{ Location } & \multicolumn{3}{|c|}{0.780} & \multicolumn{2}{|c|}{18.606} & $<0.01$ \\
\hline Q22 & Layout & & & 0.840 & & Sca & ing & $<0.01$ \\
\hline Q21 & Layout & & & 0.591 & & 13 & & $<0.01$ \\
\hline Q20 & Layout & & & 0.803 & & 16. & 76 & $<0.01$ \\
\hline Q19 & Layout & & & 0.790 & & & 87 & $<0.01$ \\
\hline Q26 & Human res & & & 0.751 & & 17 & & $<0.01$ \\
\hline Q25 & Human res & & & 0.744 & & 17. & & $<0.01$ \\
\hline Q24 & Human res & & & 0.789 & & 23 & & $<0.01$ \\
\hline Q23 & Human res & & & 0.787 & & Sca & ing & $<0.01$ \\
\hline Q3 & Design & & & 0.825 & & & & $<0.01$ \\
\hline Q2 & Design & & & 0.863 & & & ing & $<0.01$ \\
\hline Q1 & Design & & & 0.826 & & & & $<0.01$ \\
\hline Q13 & Capacity & & & 0.595 & & & & $<0.01$ \\
\hline Q9 & Capacity & & & 0.679 & & & ing & $<0.01$ \\
\hline Q14 & Capacity & & & 0.559 & & & & $<0.01$ \\
\hline Q27 & Shoppers' & lbeing & & 0.722 & & & 01 & $<0.01$ \\
\hline Q28 & Shoppers' & lbeing & & 0.785 & & Sca & ing & $<0.01$ \\
\hline Q29 & Shoppers' & lbeing & & 0.672 & & & 44 & $<0.01$ \\
\hline Depen & t variables & Impact & Indeper & dent variables & $\begin{array}{l}\text { Stan } \\
\text { path }\end{array}$ & & $t$-value & $p$-value \\
\hline Qualit & & 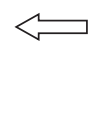 & $\begin{array}{l}\text { Location } \\
\text { and excl } \\
\text { model) }\end{array}$ & $\begin{array}{l}\text { (not significant } \\
\text { uded from the }\end{array}$ & & & - & - \\
\hline Qualit & & 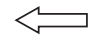 & Layout & & & & 3.38 & $<0.01$ \\
\hline Qualit & & 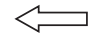 & Design & & & & 4.538 & $<0.01$ \\
\hline Qualit & & $<$ & Capacity & & & & 1.434 & $<0.10$ \\
\hline Qualit & & 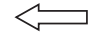 & Human $r$ & esources & & & 7.159 & $<0.01$ \\
\hline Huma & sources & 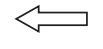 & Location & & & & 3.910 & $<0.01$ \\
\hline Huma & sources & $<$ & Layout & & & & 3.443 & $<0.01$ \\
\hline Humal & sources & 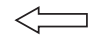 & Design & & & & 1.545 & $<0.10$ \\
\hline
\end{tabular}


Table 5 (continued)

\begin{tabular}{|c|c|c|c|c|c|}
\hline Dependent variables & Impact & Independent variables & $\begin{array}{c}\text { Standardised } \\
\text { path coefficient }\end{array}$ & $t$-value & $p$-value \\
\hline Human resources & 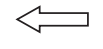 & Capacity & 0.295 & 1.962 & $<0.05$ \\
\hline Shoppers' wellbeing & 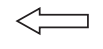 & Quality & 0.363 & 6.179 & $<0.01$ \\
\hline Shoppers' wellbeing & 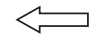 & Human resources & 0.423 & 7.177 & $<0.01$ \\
\hline
\end{tabular}

\section{Path Coefficients on Quality}

In this study, one of the four structural decisions areas was location, while one of the infrastructural decision areas was quality. Although both indicators had significant factor loadings, standing at $p=<0.01$, it was observed that location did not have a significant impact on the quality decision of the respondents. This finding indicates that location is not a significant indicator of quality based on the customers' point-of-view. Therefore, the path was excluded at the refining phase of the model.

One of the structural decision areas identified was layout. It was used to explain the internal distribution of the shops, dining and entertainment areas, and how easy it was for customers to find them. Based on the results of the factor loadings and the hypothesis, it was observed that the layout strategy had a significant impact on quality management, standing at $p=<0.01$. This shows that the layout variable plays an important role in the quality perception of shopping mall customers.

An additional structural decision area, design, was also considered. This was based on the architectural fitness and suitability of the shopping malls, as design would also depict the visual beauty of the malls. The results showed that design has a significant factor loading, standing at $p=<0.01$, and it also had a significant impact on quality, standing at $p=<0.01$. This outcome suggests that the design of a shopping mall is important for the quality perception of the shopping mall customer.

Capacity was also utilised as another structural decision area. In this study, capacity was considered based on the spaces of the shops and the dining and entertaining areas that were most utilised by shopping mall customers. The results showed that capacity planning had a significant factor loading, standing at $p=<0.01$. Capacity planning also had a significant impact on quality, standing at $p=<0.10$. This outcome shows that capacity planning decisions are significantly important in increasing the quality perception of shopping mall customers. 
Human resources planning was the only infrastructural decision area that had been tested to observe whether it had an impact on quality. Here, it was noted that human resources planning, standing at $p=<0.01$, had a significant impact on the quality perception of shopping mall customers.

\section{Path Coefficients on Human Resources}

In this study, human resources planning was considered an infrastructural decision area. This study found that it had significant factor loadings, standing at $p=<0.01$. It was further noted that location had a significant path coefficient on the human resources decision area, standing at $p=<0.01$. In addition, observations showed that design, capacity, and layout also had a significant path coefficient on human resources. Both location and layout strategies had a significant impact, standing at $p=<0.01$, while capacity planning was $p=<0.05$ and design was $p=<0.10$.

\section{Path Coefficients on Shoppers' Wellbeing}

El Hedhli et al. (2013) noted that shoppers' wellbeing can illustrate the emotional state of satisfaction with life, which shoppers may experience in relation to their cumulative shopping experiences at a mall. Although shoppers' wellbeing is not equivalent to customers' satisfaction, it can be used to determine how some aspects of a shopping mall can contribute to the quality of life of shoppers.

The outcome of this study showed, first, that the dimensions for determining shoppers' wellbeing all carried a significant factor load of $p=<0.01$. Moreover, it appears that quality in the shopping malls had a significant impact on shoppers' wellbeing, standing at $p=<0.01$. The overall results also indicate that quality decisions made by the shopping malls' management can significantly and positively impact shoppers' wellbeing. Second, decisions made about human resources also had a significant impact on the shoppers' wellbeing, standing at $p=<0.01$. This finding showed that professionalism, helpfulness, friendliness of behaviour, and the professional dress of employees in the mall contributes to shoppers' wellbeing.

\section{Explained Variance of Shoppers' Wellbeing}

Explained variance is represented by the adjusted $\mathrm{R}^{2}$ noted in the analysis. It is used to refer to the reasons why customers behaved in certain ways, as shown in Table 6. The explained variance of the shoppers' wellbeing is portrayed by each dimension. The $\mathrm{R}^{2}$ change determines the marginal variance. Initially, it was observed that the structural and infrastructural decision areas could explain $46.4 \%$ of the overall variance of the shoppers' wellbeing. Separately, the infrastructural 
decision areas helped to explain $35.3 \%$ of the overall variance, while the structural decision areas helped to explain only $11.1 \%$.

Table 6

The results of hierarchical regression analysis

\begin{tabular}{lcccccccccc}
\hline & & & & & & \multicolumn{5}{c}{ Change statistics } \\
\cline { 6 - 10 } Model & $\mathrm{R}$ & $\mathrm{R}^{2}$ & $\begin{array}{c}\text { Adjusted } \\
\mathrm{R}^{2}\end{array}$ & $\begin{array}{c}\text { Std. error of } \\
\text { the estimate }\end{array}$ & $\begin{array}{c}\mathrm{R}^{2} \\
\text { change }\end{array}$ & $\begin{array}{c}\mathrm{F} \\
\text { change }\end{array}$ & df1 & df2 & $\begin{array}{c}\text { Sig. F } \\
\text { change }\end{array}$ \\
\hline Design & 0.53 & 0.28 & 0.28 & 0.8370 & 0.28 & 225.80 & 1 & 573 & 0.000 \\
Quality & 0.61 & 0.37 & 0.37 & 0.7853 & 0.09 & 78.798 & 1 & 572 & 0.000 \\
Capacity & 0.64 & 0.41 & 0.41 & 0.7600 & 0.041 & 39.743 & 1 & 571 & 0.000 \\
Location & 0.65 & 0.43 & 0.42 & 0.7510 & 0.015 & 14.874 & 1 & 570 & 0.000 \\
Layout & 0.67 & 0.45 & 0.44 & 0.7389 & 0.019 & 19.741 & 1 & 569 & 0.000 \\
Human & 0.69 & 0.47 & 0.46 & 0.7231 & 0.024 & 26.124 & 1 & 568 & 0.000 \\
resources & & & & & & & & & & \\
\hline
\end{tabular}

By isolating each variable separately, it appears that design helped to explain $28.3 \%$ of the overall variance on shoppers' wellbeing $(p=<0.01)$. Following this is quality, which explained $8.7 \%$ of the overall variance on shoppers' wellbeing $(p=<0.01)$. Next was capacity, which helped explain $4.1 \%$ of the overall variance of shoppers' wellbeing $(p=<0.01)$. In addition, as a structural decision area, location impacted the human resources decisions significantly. It helped explain $1.5 \%$ of the overall variance of shoppers' wellbeing, while layout helped explain $1.9 \%$. Finally, human resources helped explain $2.4 \%$ of the overall variance of shoppers' wellbeing. The final, best fitting model of the study can be seen in the Figure 2.

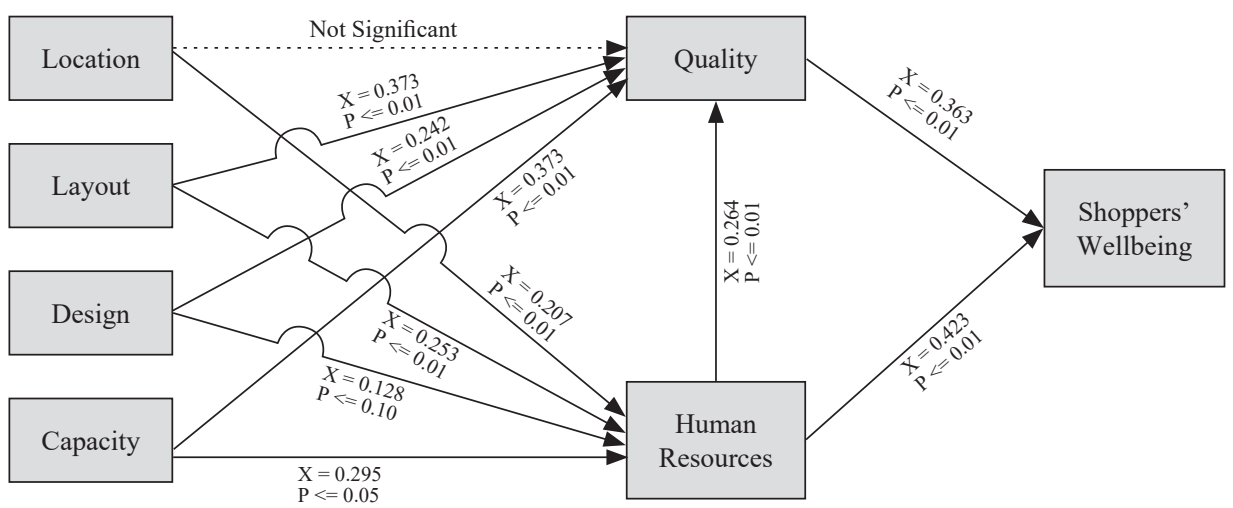

Figure 2. Best fitting model

Note: $\mathrm{X}=$ coefficient of the variable, $\mathrm{P}=$ significance of the variable 


\section{DISCUSSIONS}

The previous section has shown that various studies have focused on other attributes of shopping malls on shoppers' wellbeing, but none had explored how strategic decision areas made by the operations management impacted shoppers' wellbeing. This study contributes to the expansion of literature in that regard. Dogu and Erkip (2000), Turley and Chebat (2002), and Chebat and Morrin (2007) have noted the impact of design in shopping malls on customers' behaviour. This study had similar findings as those researchers, and it can be said that the design of shopping malls significantly impacts customers' wellbeing during their visits.

Furthermore, El Hedhli et al. (2013) found that location, layout, and (partially) capacity had a significant impact on shoppers' wellbeing. The outcome of the current study showed that capacity, location, design, and layout are significantly important for the wellbeing of shopping mall customers.

Hudson (1995) and Henry (1994) have expressed the impact of location on organisational success in the service industry. This study shows that location is not a significant impactor of quality that is perceived by customers. Thus, it may not be that important in the shopping mall sector, as they have expressed. This result may be because the cities of the Kurdistan Region of Iraq are not large enough to worry about their location or how far or close together they are.

Although El Hedhli et al. (2013) has shown that the attributes of shopping malls play important roles in shaping shoppers' wellbeing, thereby harnessing their loyalty, this study extends those findings by indicating that the impact of operational strategic decision areas cannot be underestimated. It appears that structural decision areas can be used to explain more of shoppers' wellbeing variance $(35.3 \%)$ than infrastructural decision areas (11.1\%). This result shows that the structural decision areas are more important than the infrastructural strategic decision areas in shopping malls. Thus, managers need to be careful when they decide on structural decision areas due to the cost or difficulty changing areas after initiation.

\section{CONCLUSION}

In organisations, operations management is one of three vital departments. This department has 10 strategic decision areas that can determine the success of the department. These 10 strategic decision areas can further be divided into two parts: structural decision areas and infrastructural decision areas. This study notes that 
only some of these structural decision areas and some infrastructural decision areas (design, layout, location, capacity, human resources, and quality management) are perceptible by customers while some others (inventory control, maintenance, supply-chain management, and scheduling) cannot be perceived by them.

The outcome derived from this study has shown the impact of shopping malls' operational strategic decision areas on shoppers' wellbeing. Based on the outcome, it is believed that this area of investigation, the operations management field, remains an underestimated factor in determining shoppers' wellbeing in the Kurdistan Region of Iraq. Since this element can be used to explain approximately $46 \%$ of the reasons why shoppers project quality perceptions of those shopping malls, it needs to be taken into consideration in future studies.

Initially, the study emphasised the importance of the structural decision areas, which are location, layout, design, and capacity, that impact the quality of human resource management of the shopping malls. The study has proved that structural decision areas have a significant impact on the infrastructural decision areas of operations management department in shopping malls.

Quality perceptions of customers have been an important tool in every sector recently. This study has proved that quality perception, as an infrastructural decision area, is significantly important for the wellbeing of shopping mall visitors. Thus, determinants of quality that have been elaborated in this study are also important for shopping mall management.

Another element that is considered an infrastructural decision area in this study is human resource management. The study emphasises the importance of human resource management for the improvement of shopping mall visitors' wellbeing. The study shows that human resource management impacts the wellbeing of shoppers to some extent.

Finally, the shoppers' wellbeing has been an important issue for commercial places such as shopping malls. Because these locations are where people socialise and refresh themselves, they need to feel comfortable during the time they spend there. This study concludes that design, layout, location, and capacity indirectly affect shoppers' wellbeing through quality management and human resource management.

Similar to most research, this study is limited to only one region, in this case, the Kurdistan Region of Iraq. The results and findings cannot be generalised for the whole of Iraq. Moreover, this study only considered six variables as structural 


\section{Ahmet Demir}

and infrastructural decision areas. Future studies may want to consider inventory control, maintenance, supply-chain management, and scheduling as variables in investigating their impact on shoppers' wellbeing. In addition, this study only evaluated shoppers' wellbeing and not customer satisfaction and loyalty. Thus, these topics need to be clearly distinguished when considering future studies.

As it was discussed in the discussion section, Hudson (1995) and Henry (1994) have expressed the impact of location on organisational success in the service industry. This study shows that location is not a significant impactor of quality that is perceived by customers. Thus, the impact of location in the shopping malls sector should be reinvestigated in other regions and perhaps in larger cities.

\section{APPENDIX}

Constructs and scales

\begin{tabular}{|c|c|c|c|c|c|}
\hline Design & & & & & \\
\hline This mall architecturally looks beautiful. & 1 & 2 & 3 & 4 & 5 \\
\hline This mall has been decorated suitably. & 1 & 2 & 3 & 4 & 5 \\
\hline The overall design of the mall looks nice. & 1 & 2 & 3 & 4 & 5 \\
\hline \multicolumn{6}{|l|}{ Quality } \\
\hline I can see the continuous improvement of facilities in this mall. & 1 & 2 & 3 & 4 & 5 \\
\hline I think the management of this mall is good. & 1 & 2 & 3 & 4 & 5 \\
\hline This shopping mall provides me good customer services. & 1 & 2 & 3 & 4 & 5 \\
\hline I can say that the quality of this mall is high. & 1 & 2 & 3 & 4 & 5 \\
\hline \multicolumn{6}{|l|}{ Capacity } \\
\hline Spaces of shops inside the mall are sufficient. & 1 & 2 & 3 & 4 & 5 \\
\hline $\begin{array}{l}\text { Spaces of the dining and entertainment facilities inside the } \\
\text { mall are sufficient. }\end{array}$ & 1 & 2 & 3 & 4 & 5 \\
\hline The capacity of the garage is sufficient. & 1 & 2 & 3 & 4 & 5 \\
\hline \multicolumn{6}{|l|}{ Location } \\
\hline I can easily reach the location of this mall. & 1 & 2 & 3 & 4 & 5 \\
\hline There are various ways to reach this mall. & 1 & 2 & 3 & 4 & 5 \\
\hline Generally, there is no traffic jam while driving to this mall. & 1 & 2 & 3 & 4 & 5 \\
\hline The location of this mall has been selected well. & 1 & 2 & 3 & 4 & 5 \\
\hline
\end{tabular}


Appendix (continued)

Design

Layout design

In this mall, it is easy to find the shopping stores.

In this mall, it is easy to find the food and entertainment areas.

In this mall, it is easy to find the restrooms.

Overall, the layout of this mall is very convenient.

$\begin{array}{lllll}1 & 2 & 3 & 4 & 5 \\ 1 & 2 & 3 & 4 & 5 \\ 1 & 2 & 3 & 4 & 5 \\ 1 & 2 & 3 & 4 & 5\end{array}$

Human resources

In this mall, employees are very friendly.

$\begin{array}{lllll}1 & 2 & 3 & 4 & 5\end{array}$

In this mall, employees are very helpful to the customers.

In this mall, employees are professionally dressed.

$\begin{array}{lllll}1 & 2 & 3 & 4 & 5\end{array}$

In this mall, employees are behaving professionally.

$\begin{array}{lllll}1 & 2 & 3 & 4 & 5\end{array}$

$\begin{array}{lllll}1 & 2 & 3 & 4 & 5\end{array}$

Shopper wellbeing

This mall satisfies my overall shopping needs.

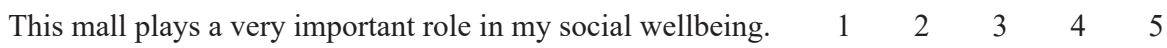

This mall plays a very important role in my leisure wellbeing. $\begin{array}{llllll}1 & 2 & 3 & 4 & 5\end{array}$

\section{REFERENCES}

Ahmed, H.M. (2016). Ethnopharmacobotanical study on the medicinal plants used by herbalists in Sulaymaniyah Province, Kurdistan, Iraq. Journal of Ethnobiology and Ethnomedicine, 12(1), 1-17. https://doi.org/10.1186/s13002-016-0081-3

Alary Gauvreau, C., Kairy, D., Mazer, B., Guindon, A., \& Le Dorze, G. (2018). Rehabilitation strategies enhancing participation in shopping malls for persons living with a disability. Disability and Rehabilitation, 40(8), 917-925. https://doi. org/10.1080/09638288.2017.1280093

Anderson, L., Ostrom, A.L., Corus, C., Fisk, R.P., Gallan, A.S., Giraldo, M., \& Shirahada, K. (2013). Transformative service research: An agenda for the future. Journal of Business Research, 66(8), 1203-1210. https://doi.org/10.1016/j. jbusres.2012.08.013

Anselmsson, J. (2006). Sources of customer satisfaction with shopping malls: A comparative study of different customer segments. The International Review of Retail, Distribution and Consumer Research, 16(1), 115-138. https://doi. org/10.1080/09593960500453641

Bloch, P.H., Ridgway, N.M., \& Dawson, S.A. (1994). The shopping mall as consumer habitat. Journal of Retailing, 70(1), 23-42. https://doi.org/10.1016/00224359(94)90026-4

Buffa, E.S. (1984). Meeting the competitive challenge: Manufacturing strategy for US companies. Homewood, IL: Dow Jones-Irwin. 
Byrne, B.M. (2001). Structural equation modeling with AMOS: Basic concepts, applications, and programming. New York: Psychology Press, https://doi. org/10.4324/9781410600219

Chebat, J.C., Gélinas-Chebat, C., \& Therrien, K. (2005). Lost in a mall, the effects of gender, familiarity with the shopping mall and the shopping values on shoppers' wayfinding processes. Journal of Business Research, 58(11), 1590-1598. https://doi.org/10.1016/j.jbusres.2004.02.006

Chebat, J.C., \& Morrin, M. (2007). Colors and cultures: Exploring the effects of mall decor on consumer perceptions. Journal of Business Research, 60(3), 189-196. https:// doi.org/10.1016/j.jbusres.2006.11.003

Chotipanich, S., \& Issarasak, S. (2017). A study of facility management operation strategy in shopping malls: Insights from 4 top-class shopping malls in Bangkok. Property Management, 35(3), 236-253. https://doi.org/10.1108/pm-07-2015-0029

Collier, D.A., \& Evans, J.R. (2014). OM 5. Boston, MA: Cengage Learning.

Cronbach, L.J. (1951). Coefficient alpha and the internal structure of tests. Psychometrika, 16(3), 297-334. https://doi.org/10.1007/bf02310555

Crosby, P.B., \& Free, Q.I. (1979). The art of making quality certain. New York: New American Library, 17.

Damali, U., Miller, J.L., Fredendall, L.D., Moore, D., \& Dye, C.J. (2016). Co-creating value using customer training and education in a healthcare service design. Journal of Operations Management, 47-48(1), 80-97. https://doi.org/10.1016/j. jom.2016.10.001

Day, R.L. (1987). Relationships between life satisfaction and consumer satisfaction: Marketing and the quality of life interface. New York: Quorum Books.

Demir, A., Özmen, Ö., \& Rashid, A. (2014). An estimation of Turkey's export loss to Iraq. Procedia -Social and Behavioral Sciences, 150, 1240-1247. https://doi. org/10.1016/j.sbspro.2014.09.140

Deming, W.E., \& Edwards, D.W. (1982). Quality, productivity, and competitive position (vol. 183). Cambridge, MA: Massachusetts Institute of Technology, Center for Advanced Engineering Study.

Dennis, C., Alamanos, E., Papagiannidis, S., \& Bourlakis, M. (2015). Does social exclusion influence multiple channel use? The interconnections with community, happiness and wellbeing. Journal of Business Research, 69(3), 1061-1070. https://doi. org/10.1016/j.jbusres.2015.08.019

Díaz Garrido, E., Martin-Pena, M.L., \& Garcia-Muina, F. (2007). Structural and infrastructural practices as elements of content operations strategy: The effect on a firm's competitiveness. International Journal of Production Research, 45(9), 2119-2140. https://doi.org/10.1080/00207540600735480

Dick, A.S., \& Basu, K. (1994). Customer loyalty: Toward an integrated conceptual framework. Journal of the Academy of Marketing Science, 22(2), 99-113. https:// doi.org/10.1177/0092070394222001

Dogu, U., \& Erkip, F. (2000). Spatial factors affecting wayfinding and orientation: A case study in a shopping mall. Environment and Behavior, 32(6), 731-755. https://doi. org/10.1177/00139160021972775 
El Hedhli, K., Chebat, J.C., \& Sirgy, M.J. (2013). Shopping well-being at the mall: Construct, antecedents, and consequences. Journal of Business Research, 66(7), 856-863. https://doi.org/10.1016/j.jbusres.2011.06.011

Espino-Rodríguez, T.F., \& Gil-Padilla, A.M. (2015). The structural and infrastructural decisions of operations management in the hotel sector and their impact on organizational performance. Tourism and Hospitality Research, 15(1), 3-18. https://doi.org/10.1177/1467358414553866

Fan, Y., French, M.L., Duray, R., \& Stading, G.L. (2017). Service strategy to improve operational capabilities in the public sector. The Service Industries Journal, 37(11-12), 703-725. https://doi.org/10.1080/02642069.2017.1304928

Feinberg, R.A., \& Meoli, J. (1991). A brief history of the mall. In R.H. Holman, \& M.R. Solomon (Eds.), Advances in consumer research (vol. 18, pp. 426-427). Provo, UT: Association for Consumer Research.

Field, A. (2000). Discovering statistics using SPSS for Windows: Advanced techniques for beginners (Introducing Statistical Methods Series). London: Sage Publications.

Fine, C.H., \& Hax, A.C. (1985). Manufacturing strategy: A methodology and an illustration. Interfaces, 15(6), 28-46. https://doi.org/10.1287/inte.15.6.28

Fornell, C., \& Larcker, D.F. (1981). Evaluating structural equation models with unobservable variables and measurement error. Journal of Marketing Research, 18(1), 39-50. https://doi.org/10.1177/002224378101800104

Goldstein, S.M., Ward, P.T., Leong, G.K., \& Butler, T.W. (2002). The effect of location, strategy, and operations technology on hospital performance. Journal of Operations Management, 20(1), 63-75. https://doi.org/10.1016/s0272-6963(01)00081-x

Garvin, D.A., \& Quality, W.D.P.(1984). What does quality really mean? Sloan Management Review, 25(1), 25-43.

Graham, E. (1988). The call of the mall. The Wall Street Journal, (May 13), 7R.

Hair, J.F., Black, W.C., Babin, B.J., Anderson, R.E., \& Tatham, R.L. (2006). Multivariate data analysis (6th ed.). New Jersey: Pearson-Prentice Hall.

Halkjær, S., \& Lueg, R. (2017). The effect of specialization on operational performance: A mixed-methods natural experiment in Danish healthcare services. International Journal of Operations \& Production Management, 37(7), 822-839. https://doi. org/10.1108/ijopm-03-2015-0152

Hami, A., Moula, F.F., \& Maulan, S.B. (2018). Public preferences toward shopping mall interior landscape design in Kuala Lumpur, Malaysia. Urban Forestry \& Urban Greening, 30(March), 1-7. https://doi.org/10.1016/j.ufug.2017.12.019

Harvey, J. (1990). Operations management in professional service organisations: A typology. International Journal of Operations \& Production Management, 10(4), 5-15. https://doi.org/10.1108/01443579010144458

Hayes, R.H., \& Wheelwright, S.C. (1984). Restoring our competitive edge: Competing through manufacturing (vol. 8). New York: John Wiley \& Sons.

Heineke, J. (1995). Strategic operations management decisions and professional performance in US HMOs. Journal of Operations Management, 13(4), 255-272. https://doi.org/10.1016/0272-6963(95)00035-6 
Herrmann, A., Huber, F., \& Braunstein, C. (2000). Market-driven product and service design: Bridging the gap between customer needs, quality management, and customer satisfaction. International Journal of Production Economics, 66(1), 77-96. https://doi.org/10.1016/s0925-5273(99)00114-0

Heizer, J., \& Render, B. (2011). Operations management (10th ed.). New Jersey: Prentice Hall.

Heizer, J., Render, B., Munson, C., \& Sachan, A. (2017). Operations management: Sustainability and supply chain management, 12/e. New Delhi: Pearson Education.

Henry, W.F. (1994). Reinventing rural hospitals. Trustee: The Journal for Hospital Governing Boards, 47(8), 22-23.

Hill, T. (1993). The essence of operations management. United States: Pearson Education.

Hu, H., \& Jasper, C.R. (2004). Men and women: A comparison of shopping mall behavior. Journal of Shopping Center Research, 11(1), 113-131.

Hudson, T. (1995). Rural priorities. Hospital links and managed care contracts top the list. Hospitals \& Health Networks, 69(4), 40-42.

Hyer, N.L., Wemmerlöv, U., \& Morris Jr., J.A. (2009). Performance analysis of a focused hospital unit: The case of an integrated trauma center. Journal of Operations Management, 27(3), 203-219. https://doi.org/10.1016/j.jom.2008.08.003

Ivanov, D., Tsipoulanidis, A., \& Schönberger, J. (2017). Layout planning. In D. Ivanov, A. Tsipoulanidis, \& J. Schönberger, Global supply chain and operations management: A decision-oriented introduction to the creation of value (pp. 279-300). Springer International Publishing. https://doi.org/10.1007/978-3-31994313-8_10

Israel, G.D. (1992). Determining sample size (Fact sheet PEOD-6). United States: University of Florida.

Juran, J.M. (1988). Juran's quality handbook. New York: Free Press.

Jones, P., \& Lockwood, A. (1998). Operations management research in the hospitality industry. International Journal of Hospitality Management, 17(2), 183-202. https://doi.org/10.1016/s0278-4319(98)00015-2

Keng, C.J., Huang, T.L., Zheng, L.J., \& Hsu, M.K. (2007). Modeling service encounters and customer experiential value in retailing: An empirical investigation of shopping mall customers in Taiwan. International Journal of Service Industry Management, 18(4), 349-367. https://doi.org/10.1108/09564230710778137

Kesari, B., \& Atulkar, S. (2016). Satisfaction of mall shoppers: A study on perceived utilitarian and hedonic shopping values. Journal of Retailing and Consumer Services, 31(July), 22-31. https://doi.org/10.1016/j.jretconser.2016.03.005

Ketokivi, M., Turkulainen, V., Seppälä, T., Rouvinen, P., \& Ali-Yrkkö, J. (2017). Why locate manufacturing in a high-cost country? A case study of 35 production location decisions. Journal of Operations Management, 49-51(1), 20-30. https:// doi.org/10.1016/j.jom.2016.12.005

Kim, H.K. (2014). The effect of authentic leadership on employees' attitudes, behaviors, and performances in a Korean context. $\mathrm{PhD}$ dissertation, Oklahama State University.

Kim, J.O., \& Jin, B. (2001). Korean consumers' patronage of discount stores: Domestic vs multinational discount store shoppers' profiles. Journal of Consumer Marketing, 18(3), 236-255. https://doi.org/10.1108/07363760110393092 
Kim, J.S., \& Arnold, P. (1996). Operationalizing manufacturing strategy: An exploratory study of constructs and linkage. International Journal of Operations \& Production Management, 16(12), 45-73. https://doi.org/10.1108/01443579610151751

Kim, Y., \& Lee, J. (1993). Manufacturing strategy and production systems: an integrated framework. Journal of Operations Management, 11(1), 3-15.

Khine, M.S. (2013). Application of structural equation modeling in educational research and practice (vol. 7). Rotterdam, NL: Sense Publishers.

Krajewski, L.J., \& Ritzman, L.P. (2000). Operations management: Strategy and analysis. New York: Adisson Wesley.

Lee, D.J., Sirgy, M.J., Larsen, V., \& Wright, N.D. (2002). Developing a subjective measure of consumer well-being. Journal of Macromarketing, 22(2), 158-169. https://doi. org/10.1177/0276146702238219

Lehew, M.L.A., Burgess, B., \& Wesley, S. (2002). Expanding the loyalty concept to include preference for a shopping mall. The International Review of Retail, Distribution and Consumer Research, 12(3), 225-236. https://doi. org/10.1080/09593960210139643

Li, L.X., Benton, W.C., \& Leong, G.K. (2002). The impact of strategic operations management decisions on community hospital performance. Journal of Operations Management, 20(4), 389-408. https://doi.org/10.1016/s0272-6963(02)00002-5

Marsh, H.W., \& Hocevar, D. (1988). A new and more powerful approach to multi trait multimethod analyses: Application of second-order confirmatory factor analysis. Journal of Applied Psychology, 73(1), 107-117. https://doi.org/10.1037//00219010.73.1.107

Messner, M. (2016). Does industry matter? How industry context shapes management accounting practice. Management Accounting Research, 31(June), 103-111. https://doi.org/10.1016/j.mar.2015.09.001

Michon, R., \& Chebat, J.C. (2004). Cross-cultural mall shopping values and habitats: A comparison between English- and French-speaking Canadians. Journal of Business Research, 57(8), 883-892. https://doi.org/10.1016/s0148-2963(02)00291-6

Mohar, A.H.A., Abdullah, F., \& Ho, V.B. (2016). Development and validations of a holistic service operations management instrument. Procedia - Social and Behavioral Sciences, 224(June), 429-436. https://doi.org/10.1016/j.sbspro.2016.05.414

Narasimhan, R., Swink, M., \& Kim, S.W. (2005). An exploratory study of manufacturing practice and performance interrelationships: Implications for capability progression. International Journal of Operations \& Production Management, 25(10), 1013-1033. https://doi.org/10.1108/01443570510619509

Noble, M.A. (1995). Manufacturing strategy: Testing the cumulative model in a multiple country context. Decision Sciences, 26(5), 693-721. https://doi. org/10.1111/j.1540-5915.1995.tb01446.x

Nunnally, J. (1978). Psychometric methods. New York: McGraw-Hill.

Olobatuyi, M.E. (2006). A user's guide to path analysis. Lanham, Maryland: University Press of America.

Ong, A.D., \& van Dulmen, M.H. (2007). Oxford handbook of methods in positive psychology. New York: Oxford University Press. 
Osman, H., Johns, N., \& Lugosi, P. (2014). Commercial hospitality in destination experiences: McDonald's and tourists' consumption of space. Tourism Management, 42(June), 238-247. https://doi.org/10.1016/j.tourman.2013.12.009

Papagiannidis, S., Bourlakis, M., Alamanos, E., \& Dennis, C. (2017). Preferences of smart shopping channels and their impact on perceived wellbeing and social inclusion. Computers in Human Behavior, 77(December), 396-405. https://doi. org/10.1016/j.chb.2017.04.029

Patel, P.C., Guedes, M.J., \& Pearce, J.A. (2017). The role of service operations management in new retail venture survival. Journal of Retailing, 93(2), 241-251. https://doi. org/10.1016/j.jretai.2017.03.001

Prince, J.B. (1994). Performance appraisal and reward practices for total quality organizations. Quality Management Journal, 1(2), 36-46. https://doi.org/10.1080 /10686967.1994.11918645

Raajpoot, N.A., Sharma, A., \& Chebat, J.C. (2008). The role of gender and work status in shopping center patronage. Journal of Business Research, 61(8), 825-833. https://doi.org/10.1016/j.jbusres.2007.09.009

Ren, H., \& Huang, T. (2017). Modeling customer bounded rationality in operations management: A review and research opportunities. Computers and Operations Research, 91(March), 48-58. https://doi.org/10.1016/j.cor.2017.11.002

Rook, K.S. (2015). Social networks in later life: Weighing positive and negative effects on health and well-being. Current Directions in Psychological Science, 24(1), 45-51. https://doi.org/10.1177/0963721414551364

Roth, A.V., \& van Dierdonck, R. (1995). Hospital resource planning: Concepts, feasibility, and framework. Production and Operations Management, 4(1), 2-29. https://doi. org/10.1111/j.1937-5956.1995.tb00038.x

Rosenbaum, M.S., Otalora, M.L., \& Ramírez, G.C. (2016). The restorative potential of shopping malls. Journal of Retailing and Consumer Services, 31, 157-165. https://doi.org/10.1016/j.jretconser.2016.02.011

Roy, A. (1994). Correlates of mall visit frequency. Journal of Retailing, 70(2), 139-161.

Saunders, N.K. (2000). Research methods for business students (2nd ed.). Essays, England: Financial Times/Prentice Hall.

Shah, R., \& Goldstein, S.M. (2006). Use of structural equation modeling in operations management research: Looking back and forward. Journal of Operations Management, 24(2), 148-169. https://doi.org/10.1016/j.jom.2005.05.001

Shang, Y., Li, B., Baldwin, A.N., Ding, Y., Yu, W., \& Cheng, L. (2016). Investigation of indoor air quality in shopping malls during summer in Western China using subjective survey and field measurement. Building and Environment, 108(November), 1-11. https://doi.org/10.1016/j.buildenv.2016.08.012

Sirgy, M.J., Meadow, H.L., \& Samli, A.C. (1995). Past, present, and future: An overview of quality-of-life research in marketing. In M.J. Sirgy, \& A.C. Samli (Eds.), New dimensions of marketing and quality-of-life research (pp. 335-364). Westport: Greenwood Press. 
Skinner, W. (1969). Manufacturing-missing link in corporate strategy. Harvard Business Review, 47(3), 136-145.

Smith, T.M., \& Reece, J.S. (1999). The relationship of strategy, fit, productivity, and business performance in a service setting. Journal of Operations Management, 17(2), 145-161. https://doi.org/10.1016/s0272-6963(98)00037-0

Straub, D., Boudreau, M.C., \& Gefen, D. (2004). Validation guidelines for IS positivist research. Communications of the Association for Information Systems, 13(1), 380-427. https://doi.org/10.17705/1 cais.01324

Subramanian, N., \& Ramanathan, R. (2012). A review of applications of analytic hierarchy process in operations management. International Journal of Production Economics, 138(2), 215-241. https://doi.org/10.1016/j.ijpe.2012.03.036

Swamidass, P.M., \& Newell, W.T. (1987). Manufacturing strategy, environmental uncertainty and performance: A path analytic model. Management Science, 33(4), 509-524. https://doi.org/10.1287/mnsc.33.4.509

Swink, M., Narasimhan, R., \& Kim, S.W. (2005). Manufacturing practices and strategy integration: Effects on cost efficiency, flexibility, and market-based performance. Decision Sciences, 36(3), 427-435. https://doi.org/10.1111/j.15405414.2005.00079.x

Taylor, M., Bates, G., \& Webster, J.D. (2011). Comparing the psychometric properties of two measures of wisdom: Predicting forgiveness and psychological well-being with the self-assessed wisdom scale (SAWS) and the three-dimensional wisdom scale (3D-WS). Experimental Aging Research, 37(2), 129-141. https://doi.org/10 $.1080 / 0361073 \times .2011 .554508$

Tsai, S.P. (2010). Shopping mall management and entertainment experience: A crossregional investigation. The Service Industries Journal, 30(3), 321-337. https://doi.org/10.1080/02642060802123376

Turley, L.W., \& Chebat, J.C. (2002). Linking retail strategy, atmospheric design and shopping behaviour. Journal of Marketing Management, 18(1-2), 125-144. https://doi.org/10.1362/0267257022775891

Ulrich, K. (1995). The role of product architecture in the manufacturing firm. Research Policy, 24(3), 419-440. https://doi.org/10.1016/0048-7333(94)00775-3

Voss, C.A. (1995). Alternative paradigms for manufacturing strategy. International Journal of Operations \& Production Management, 15(4), 5-16.

Wakefield, K.L., \& Baker, J. (1998). Excitement at the mall: Determinants and effects on shopping response. Journal of Retailing, 74(4), 515-539. https://doi.org/10.1016/ s0022-4359(99)80106-7

Wright, P.M., \& McMahan, G.C. (1992). Theoretical perspectives for strategic human resource management. Journal of Management, 18(2), 295-320.

Youndt, M.A., Snell, S.A., Dean, J.W., \& Lepak, D.P. (1996). Human resource management, manufacturing strategy, and firm performance. Academy of Management Journal, 39(4), 836-866. https://doi.org/10.2307/256714 